\title{
THE CORRELATION BETWEEN STUDENTS' VOCABULARY MASTERY AND SPEAKING SKILL
}

\author{
Bradhiansyah Tri Suryanto \\ Universitas Nurul Jadid \\ bradhiansyahs@gmail.com \\ Ahmad Arif Imron \\ Universitas Nurul Jadid \\ imronarifahmad@gmail.com \\ Diyah Ayu Rike Prasetyo \\ Universitas Nurul Jadid \\ diahayurike@gmail.com
}

\begin{abstract}
In an increasingly advanced globalization era where the ability to speak English is a must in keeping up with the times. An analysis of the correlation between vocabulary mastery and students' speaking skills in English is needed. This is because vocabulary mastery is the main point for students to have good speaking skills. This study aims to determine the relationship between vocabulary mastery and speaking skills. This research uses a quantitative approach with a correlation study type. The sample in this study was 52 respondents in the second semester of the Department of English Education, the University of Nurul Jadid using the purposive sampling technique. Data analysis using the Pearson Product Moment formula to determine whether there are a correlation and the level of correlation between mastery of English vocabulary and speaking skill..
\end{abstract}

Keywords: Correlation, Mastery of Vocabulary, Speaking Skill

\section{INTRODUCTION}

In facing global competition, the ability to use international languages is an important aspect. Language ability, especially in English, is a very important aspect in equipping human resources who will be involved in the world of work. Therefore, students must be prepared to become high-quality human resources and have useful skills, especially in terms of their language abilities. Language competence includes four things, namely, listening, speaking, reading, and writing. Language is basically aimed at communicating . This is because almost all human activities, wherever they are, are always touched by communication (Suryanto \& Nikmatillah, 2020). Because language communication skills include oral communication and written communication, it is necessary to have a balance between language competencies in the learning process.

The ability to read, listen, speak and write is a powerful tool in supporting thinking and learning skill. The ability to speak gets a contribution from reading activities. From reading activities, students will get various ideas and knowledge that can be used as material for developing speech texts or conversations on certain topics. For example, a lecturer who will deliver teaching materials to students needs to equip himself by reading from various adequate sources, such as textbooks, other related books, printed media, and electronic media, for example, the internet. By getting information from these various sources, the content of the speech or conversation will have more weight.

The ability to speak is highly dependent on student input activities (such as reading and listening) so that each student has different speaking skills even though they are given the same material during lectures. Student learning activities are influenced by various factors, such as motivation, maturity, student-lecturer relations, verbal ability, and level of freedom, security, and lecturer skills in communication. If the factors mentioned above are met, then through the lecture process, students can have good knowledge and speaking skill. 
In honing a speaking skill, adequate vocabulary mastery is required. The role of vocabulary is very important in the language learning process. The quality and quantity and depth of a person's vocabulary are the best personal indices of mental development. Besides, vocabulary development is the development of a single concept which is the goal of basic education for each university. In principle, all levels of education are vocabulary development which is also a conceptual development. Vocabulary development is influenced by age, gender, innate abilities, and social status. Geographical factors also influence vocabulary development.

Vocabulary can be arranged into phrases, clauses, and sentences using certain agreedupon rules in a language system. This series of vocabulary is then used to form ideas/ideas which are then conveyed orally when speaking. Therefore, a person's speaking skill is very dependent on the quality and quantity of his vocabulary. If someone has a higher and richer quality of vocabulary mastery, then that person has a greater chance of becoming an expert in speaking. Mastery of vocabulary is one of the first steps that students should pay attention to. Students can expand their vocabulary through reading activities. With the help of the internet and other means, language students can easily get books and reading material in the language they want. If they persistently maintain their interest in reading well, then mastery of their vocabulary will help them become more skilled in speaking a foreign language. Based on this background, the formulation of the problem in this study is focused on the effect of vocabulary mastery on the English speaking skill of students of the second semester of the English education study program at Nurul Jadid University. This study aims to prove scientifically the correlation between vocabulary mastery and English speaking skills. This research is expected to be useful as a reference for scientific studies for other research in the same field, especially in the field of language.

\section{Review of Literature Speaking}

Communication commonly carried out by humans can be classified into two forms, namely oral and written communication. Speaking is a form of oral communication and is most often done by humans. Speaking is a verbally productive ability. In-depth, speaking can be defined as a sign system that can be heard and utilizes human muscles and muscle tissue to communicate ideas through articulated sounds or words to express, express, and convey thoughts, ideas and feelings. Speaking is also understood as a form of human behavior that extensively utilizes physical, psychological, neurological, semantic, and linguistic factors so that it can be used as a very important tool for social control (Tarigan, 2008). This understanding clearly shows that speaking is related to the pronunciation of words that aim to convey what will be conveyed, be it feelings, ideas or ideas.

Experts say that there are several types of forms in conveying messages, ideas, or ideas depending on their purpose and function. Keraf distinguished the types of speaking into three types, namely persuasive, instructive and recreational(Keraf, 2007). The persuasive type of speaking is usually able to encourage, convince, and get the listener to act. Want a reaction from the listener to get inspiration or arouse emotions to get a line of opinion, intellectual, even actions from the listener. The instructive/informative speaking type desires a reaction from the listener in the form of an appropriate understanding. Recreational speaking is fun and wants a reaction from the listener in the form of interest and excitement. Meanwhile, Haryadi and Zamzani divided the types of speaking into two types, namely public speaking which includes speaking notification, kinship, persuasion, negotiating, and speaking at conferences, which includes group discussions, parliamentary procedures, and debate(Haryadi \& Zamzani, 1996). 
Based on these statements, it can be concluded that in essence speaking is an expression of a person's thoughts and feelings in the form of language sounds. In such a context, the ability to speak can be understood as the ability to pronounce articulated sounds or utter words to express, express, convey thoughts, ideas and feelings. Listeners receive information through a series of tones, stresses, and pauses that can be persuasive, instructive, or recreational. If communication takes place face-to-face, speaking activities can be expressed with the help of the speaker's mimic and pantomime.

\section{Skill}

According to Soemarjadi, skill is the ability to do a job deftly and correctly. Being skilled is more than just understanding, so to be skilled requires practical exercises that can stimulate the brain(Soemarjadi, n.d.). Skill according to Subana also means a person's ability to use thought or reason which results in efficient and effective actions in achieving certain results(Subana, n.d.). Skill contains several elements of ability, namely the ability to think (psychic) and the ability to do (physical). Robbins stated that basic skills can be categorized into four, namely basic literacy skill, technical skill, interpersonal skill, and problemsolving(Robbins, 2000). Basic literacy skills are definite and must-have basic literacy skills such as reading, writing, listening, and speaking. Technical skill is someone's expertise in developing his abilities in technical fields, such as operating computers, calculating accurately, and others. Interpersonal skill is a person's ability to interact with other people both in communicating and working together in a team. Meanwhile, problem-solving is a person's activity in using logic to find out the causes, develop alternatives, analyze and choose a suitable form of problem-solving.

\section{Speaking Skill}

Skill can be defined as a person's ability or ability to use thoughts, reasoning, and actions in doing something effectively and efficiently. In terms of speaking, a person can be categorized as skilled if they can speak effectively and efficiently. According to Arsjad in speaking, several factors support the effectiveness of speaking, namely linguistic and non-linguistic factors(Arsjad, 1988). Linguistic factors include accuracy in pronouncing sounds, duration, stress placement, appropriate tone of speech, choosing the right words, and using effective sentences. Meanwhile, non-language factors include flexibility in speaking, visual contact with listeners, appropriate gestures and expressions, an adequate volume of voice, fluency in speaking, and mastery of materials.

Apart from language and non-language factors, speaking skill also consists of four aspects, namely social skill, semantics, phonetics, and vocals. Social skill is the ability to participate effectively in social relationships. The social skill requires that we know what to say, how to say it, where to say it, and when not to say it. Semantic skill is the ability to use words appropriately and comprehensively. To acquire semantic skills, we must have a broad knowledge of the meanings contained in words as well as the accuracy and practicality of using these words. Phonetic skill is the ability to form the phonetic elements of our language correctly. These skills are needed because they participate in carrying out and determining social approval or rejection. Vocal skill is the ability to create the desired emotional effect with sound

\section{Speaking Skill Assessment}

At the end of each period in a lecture process, it is necessary to evaluate the results of the lecture performance. This assessment can be obtained through the procurement of tests given to students. The test is a tool to measure/determine the ability of students to follow the learning process that has been taking place. In principle, the student's speaking skills test/test 
is focused on speaking practice tests. The assessment in the speaking skill test consists of two things, namely linguistic and non-linguistic factors(Nurgiyantoro, 1995). Assessment of linguistic factors includes pronunciation / pronunciation, grammar / language structure and vocabulary / vocabulary. Meanwhile, the assessment of non-linguistic factors according to Nurgiyantoro includes calmness when speaking, appropriate volume, fluency in speaking, and understanding of the material presented(Nurgiyantoro, 1995).

\section{Mastery of Vocabulary}

Vocabulary has an important role in everyday life, especially in communication activities in the community and the lecture process on campus. Mastery of sufficient vocabulary will facilitate students' understanding of the subject matter provided by the teacher. The word in ancient Greek is also called lexicon. Some experts define vocabulary as vocabulary in a language. According to Chaer states that the term lexicon is commonly used to accommodate the concept of a collection of lexemes from a language, both in whole and in part(Chaer, 2009). The lexicon is a language component that contains all information about the meaning and usage of words in a language.

According to Keraf, vocabulary is a means of channeling ideas/ideas, which means that the more vocabulary that is mastered, the more and more fluently the idea is conveyed(Keraf, 2007). Nurgiyantoro states that vocabulary mastery is a person's ability to recognize, understand, and use words properly and correctly, by listening, speaking, reading, and writing(Nurgiyantoro, 2001). The ability to understand is manifested in reading and listening activities, while the ability to use is manifested in writing and speaking activities. Recognizing words is getting new words from listening or reading results. The essence of understanding words is acquiring new vocabulary, understanding words and their meanings, and understanding the relationship between words and concepts that begin with these words. According to Djiwandono in communicating, vocabulary is a very important element(Djiwandono, 1996). The meaning of discourse as a form of language use is largely determined by the vocabulary used in its expression. Thus, if a child cannot master vocabulary, the child will have difficulty understanding a language. In children, mastering vocabulary is not enough just to understand it, but it must also include the ability to use the vocabulary in communication activities.

Nurgiyantoro states that the ability to understand vocabulary is receptive mastery, while the ability to use vocabulary is productive mastery(Nurgiyantoro, 2001). Receptive mastery is seen when children can do reading and listening activities, while productive mastery is seen in speaking and writing activities. Yunisah suggests that vocabulary mastery is a measure of a person's understanding of the vocabulary of a language and his ability to use the vocabulary both orally and in writing(Yunisah, 2007). Mastery of vocabulary is part of the mastery of language because if someone mastered the language, it means that person mastered vocabulary. Mastery of vocabulary is very important because ideas/ideas will be easily understood if expressed with the right choice of words. By having good vocabulary mastery, speaking skills can be more developed

\section{Vocabulary Mastery Assessment}

The vocabulary test is part of the language proficiency test. This test is carried out to assess or obtain information about the results of language learning achieved by students, which indirectly will also provide information about various aspects of teaching(Djiwandono, 1996). Vocabulary tests are conducted to measure students' abilities, both receptive and productive. Thus, in the vocabulary test, receptive abilities and productive abilities must be related to one another. 
According to Nurgiyantoro in the vocabulary test, two things need to be considered, namely: (a) choosing the vocabulary to be tested and (b) choosing the form and method of testing, especially regarding the preparation of tests that are following the levels of certain cognitive aspects(Nurgiyantoro, 2001). The level of the vocabulary mastery test in this study refers to the cognitive level which is commonly called Bloom's Taxonomy. This level consists of six levels, namely the level of knowledge/memory (C1), level of understanding (C2), level of application (C3), level of analysis (C4), level of evaluation (C5), and level of creativity (C6). Nurgiyantoro states that for the cognitive level vocabulary mastery test that is used up to the level of analysis (C4) (Nurgiyantoro, 2001). Based on this opinion, the vocabulary mastery test in this study uses four levels, namely the level of memory/knowledge (C1), level of understanding (C2), level of application (C3), and level of analysis (C4). The high-level cognitive vocabulary tests (C5 and C6) were not used in this study because these cognitivelevel tests demand deeper abilities and simultaneously assess thinking processes. Besides, the C5 and C6 level vocabulary tests are more appropriate when used for essay form tests.

\section{METHOD}

This research was conducted in two classes of students of the second semester of the English education study program at Nurul Jadid University in 2020. The data collection technique was carried out by giving a written test and then the data was processed by regression and correlation analysis.

\section{Respondents}

The participants were two classes of students of the second semester of the English education study program at Nurul Jadid University in 2020.

\section{Instruments}

The instruments were written answer sheet and written test sheet.

\section{Procedures}

The procedure of collecting data technique was carried out by giving a written test and then the data was processed by regression and correlation analysis.

\section{Data Analysis \\ Regression Analysis}

Pratomo \& Astuti says that regression analysis is a branch of statistics that studies the form of the functional relationship of a variable (independent variable/predictor) to other variables (response variables) (Pratomo \& Astuti, 2015). Regression is divided into two, namely simple linear analysis and multiple linear analysis. Linear regression analysis is if the relationship of the equation between the independent variable $(\mathrm{X})$ and the variable $(\mathrm{Y})$ is unidirectional and forms a straight line pattern. So, if the variable value $(\mathrm{X})$ increases, the variable value $(\mathrm{Y})$ also increases. Vice versa, if between $(\mathrm{X})$ and $(\mathrm{Y})$ experience a negative relationship(Sudjana, 2005). Here is the formula for linear regression:

$Y=a+b x$

Information:

$\mathrm{Y}=$ Subject in the predicted dependent variable (not free).

$\mathrm{X}=$ Subject on the independent variable (free) which has a certain value.

$\mathrm{a}=$ Intercept parameter.

$\mathrm{b}=$ parameter of the independent variable regression coefficient.

(Source:(Sugiyono, 2017)) 


\section{Correlation Analysis}

Correlation analysis is used to determine the closeness of the relationship between two variables and to determine the direction of the relationship that occurs. Pearson's Product Moment correlation analysis technique is a statistical parametric technique that uses interval data with certain requirements. The data were selected randomly but still normally distributed. According to Sugiyono, the Pearson correlation equation is expressed in the formula(Sugiyono, 2008):

$$
r=\frac{n\left(\sum x i y i\right)-\left(\sum x i\right)\left(\sum y i\right)}{\sqrt{\left\{\left(n \sum x i^{2}\right)-\left(\sum x i\right)^{2}\right\}\left\{\left(n \sum y i^{2}\right)-\left(\sum y i\right)^{2}\right\}}}
$$

Meanwhile, according to Ridwan, the interpretation of the correlation coefficient is as follows(Riduwan, 2003):

Table 1. Interpretation of the Correlation Coefficient

\begin{tabular}{cc}
\hline Coefficient Interval & Relationship Level \\
\hline $0,80-1,000$ & Very strong \\
$0,60-0,799$ & Strong \\
$0,40-0,599$ & Strong enough \\
$0,20-0,399$ & Low \\
$0,00-0,199$ & Very low \\
\hline
\end{tabular}

\section{FINDINGS AND DISCUSSION}

Survey data in this research were taken from 40 respondents consisting of two different classes and processed with the help of a computer through the SPSS 16.0 program. Description of the statistics of all respondents is shown in Table 2 below.

\begin{tabular}{|c|c|c|}
\hline & $\bar{X}$ & $\bar{Y}$ \\
\hline $\begin{array}{r}\text { Valid } \\
\text { Missing }\end{array}$ & $\begin{array}{r}52 \\
0\end{array}$ & $\begin{array}{r}52 \\
0\end{array}$ \\
\hline Mean & 91,62 & 75,42 \\
\hline Median & 94,5 & 79 \\
\hline Mode & 94 & 78 \\
\hline Std. Deviation & 16.584 & 16.952 \\
\hline Variance & 275.026 & 287.386 \\
\hline Skewness & -4.821 & -3.619 \\
\hline Std. Error of Skewness & .330 & .330 \\
\hline Kurtosis & 23.484 & 14.488 \\
\hline Std. Error of Kurtosis & .650 & .650 \\
\hline Range & 100 & 100 \\
\hline Minimum & 0 & 0 \\
\hline Maximum & 100 & 100 \\
\hline
\end{tabular}

\section{Analysis of Variable Data X (Vocabulary Mastery)}

Based on Table 2 above, we can see that the maximum value of variable $\mathrm{X}$ is 100 while the minimum value is 0 . The maximum and minimum difference value or what is commonly called the range for variable $X$ is 100 . The average value of this variable $X$ is 91,62 . Meanwhile, the median value is 94,5 . This number shows that 50 percent of students have a value less than the median value. Moreover, the differences between the average value and the median value were not that great (average $=91,62$ and median $=94,5$ ) indicates that the vocabulary mastery data is sufficiently representative. Based on the numbers listed on the mode, the majority of students have the sum of the values 94 for the variable X. 
According to the size of the disperse with the standard deviation measure, it shows that the variable $\mathrm{X}$ has a value of 16,6 . While the heterogeneous level of variable $\mathrm{X}$ can be seen from the number listed in the variance column, which is 275,03 . Then when viewed from the distribution, the statistical figures show that the variable $\mathrm{X}$ has a right-skewed distribution which is indicated by a positive skewness value of -4.821 (see Figure 1). And if you look at the tapering or kurtosis, it shows that the variable $\mathrm{X}$ has a horizontal distribution pattern because the kurtosis value is negative at 23.484. The following is a histogram of variable $\mathrm{X}$ data (vocabulary mastery).

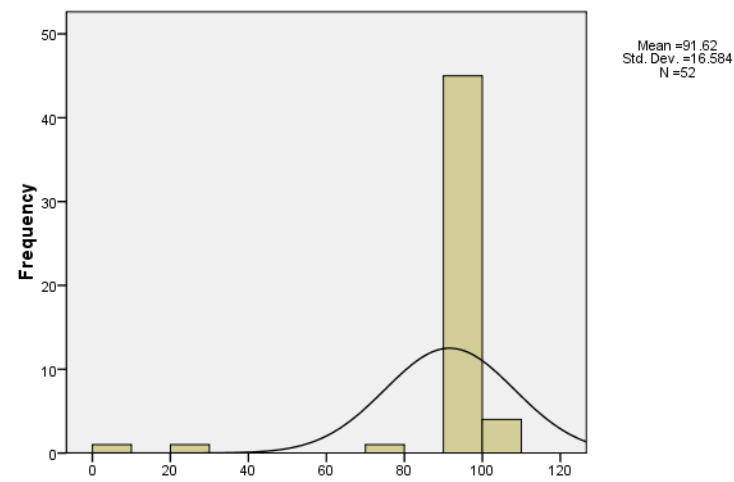

Figure 1. Histogram of Student Vocabulary Mastery Score Data

From the distribution table, histogram, and frequency polygons, it can be concluded that the vocabulary mastery score data in this study tend to be normally distributed.

\section{Analysis of Variable Data Y (Speaking Skill)}

Based on Table 2 above, we can see that the maximum value of variable $\mathrm{Y}$ is 100 while the minimum value is 0 . The maximum and minimum difference value or what is commonly called the range for variable $\mathrm{Y}$ is 100 . The average value of this $\mathrm{Y}$ variable is 75,42 . Meanwhile, the median value is 79. This figure shows that 50 percent of students have a smaller value than the median value. Besides, the differences between average value and median value were not that great (average $=75,42$ and median $=79$ ) indicating that the speaking skill data was quite representative. Based on the numbers listed in the mode, the majority of students have a total value of 78 for variable Y.

According to the size of the disperse with the standard deviation measure, it shows that the Y variable has a value of 17,0. While the heterogeneous level of the Y variable we can see from the number listed in the variance column, which is 287.39 . Then when viewed from the distribution, statistical figures show that the variable $Y$ has a left-skewed distribution which is indicated by a negative skewness value of -3.619 (see Figure 2). And if you look at the tapering or kurtosis, it shows that the $\mathrm{Y}$ variable is tapered because the kurtosis value is positive at 14.488. The following is a histogram of the $\mathrm{Y}$ variable data (speaking skills).

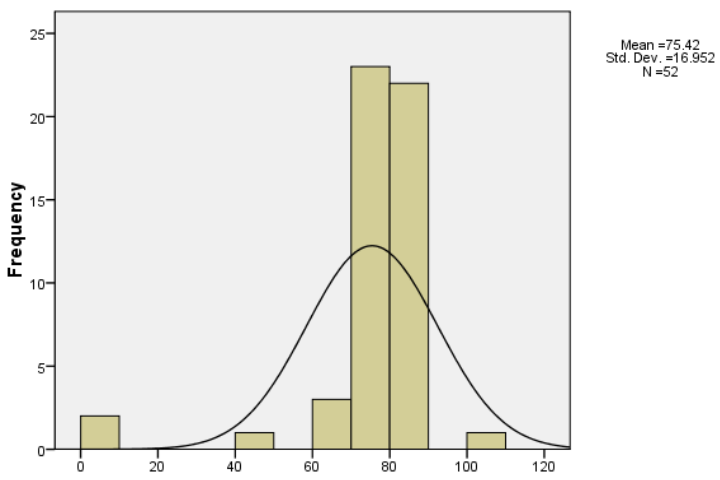

Figure 2. Histogram of Student Speaking Skills Score Data 
From the distribution table, histogram, and frequency polygons, it can be concluded that the data on students' English speaking skills scores in this study tend to be normally distributed.

\section{Regression Line Linearity Test}

Linearity testing in this study used the following hypothesis:

$\mathrm{H}_{0}$ : the regression line of the relationship between variable $\mathrm{X}$ and variable $\mathrm{Y}$ is linear $\mathrm{H}_{1}$ : the regression line of the relationship between variable $\mathrm{X}$ and variable $\mathrm{Y}$ is not linear The calculations were carried out with the help of a computer through the SPSS 16.0 program. Following with the applicable provisions of the program, the criteria for data normality are met if the $p$ value (sig) $>0.05\left(\mathrm{H}_{0}\right.$ is accepted). If $\mathrm{H}_{0}$ is accepted, the regression line is linear. The sig value is the number listed in the row sig column Deviation from Linearity in the ANOVA table, the result of the calculation of the linearity regression test using the SPSS program.

\section{The Linearity of the Regression Lines for the Relationship between $\mathrm{X}$ and $\mathrm{Y}$}

The results of the calculation of the linearity regression test for the relationship between variable $\mathrm{X}$ and variable $\mathrm{Y}$ can be seen in Table 3.

Table 3. Recapitulation of Linearity Test Results of the Regression line The relationship between Variable X and Variable Y

\begin{tabular}{lrrrrr}
\hline \multicolumn{5}{c}{ ANOVA Table } \\
\hline & Sum of Squares & df & & \\
\hline $\mathrm{y}^{*} \mathrm{x}$ Between Square & $\mathrm{F}$ & Sig. \\
& 7542.238 & 9 & 838.026 & 4.947 .000 \\
& 6690.778 & 1 & 6690.778 & 39.499 .000 \\
Within Groups & 851.460 & 8 & 106.432 & .628 .749 \\
Total & Levinearity & 7114.455 & 42 & 169.392 & \\
& & 14656.692 & 51 & & \\
\hline
\end{tabular}

From Table 3 above, we can see that the value in the Deviation from Linearity column is 0,749 which is greater than 0.05 so that $\mathrm{H}_{0}$ is accepted and this means that the regression line between variables $\mathrm{X}$ and $\mathrm{Y}$ is linear. To prove this hypothesis is to pay attention to the values/numbers listed in column t or column sig for the Vocabulary Mastery (X) row in Table 3. According to the existing provisions, the regression significance criteria is "if $t_{\text {count }}>t_{\text {table }}$ then $\mathrm{H}_{0}$ is rejected" or "if Sig<0.05 then $\mathrm{H}_{0}$ is rejected", which means that there is a significant influence on the independent variable $\mathrm{X}$ on variable $\mathrm{Y}$. The sig value is the number listed in the sig column for the Vocabulary Mastery row in Table 3. The $t_{\text {count }}$ value is the number listed in the column $t$ for the line of Vocabulary Mastery in Table 3. While the value of the $t$ table is the value of the $t$ distribution table for the real level of $5 \%$ with the degree of confidence $(\mathrm{df}=\mathrm{n}-2)=50$ where $\mathrm{n}$ is the number of respondents.

From Table 3, we can see that the value of sig $=0.000$ and $t_{\text {count }}=6,480$ while $t_{\text {table }}=$ 1,68 . Because the value of sig $<0.05$ and $\mathrm{t}_{\text {count }}>\mathrm{t}_{\text {table }}, \mathrm{H}_{0}$ is rejected, which means that there is a significant effect of variable $\mathrm{X}$ on the dependent variable Y. From the results of correlation testing, regression testing, and by looking at the line model, it can be concluded that there is a significant influence on the independent variables. $\mathrm{X}$ on the dependent variable Y. To show the amount of contribution of students' vocabulary mastery to their English skills, a partial determination coefficient analysis was carried out which results are presented in Table 4. 
Table 4. Partial Determination Coefficient with Variable X (Vocabulary Mastery) in Students

\begin{tabular}{ccc}
\hline \multirow{2}{*}{ Independent Variable } & \multicolumn{2}{c}{ Determination Coefficient } \\
\cline { 2 - 3 } & Absolute Donation & Effective Donation \\
\hline $\mathrm{X}$ & 0,676 & 45,6 \\
\hline
\end{tabular}

The results in table 4 show that the contribution of the vocabulary mastery variable $(X)$ is 45,6 percent towards students' skills in English. This result is following the synthesis of several theories which state that one of the criteria for being categorized as a skilled speaker is being able to communicate orally effectively and efficiently. Because the process of communicating requires vocabulary to represent ideas, messages or ideas to be conveyed, students who have good vocabulary mastery can be sure that it will be easier to communicate.

By having good vocabulary mastery, their speaking ability can be more developed. They can freely convey their thoughts in a foreign language because they understand the vocabulary that represents the content of the messages they will convey in English. Good command of vocabulary in English will help students to speak skillfully. Furthermore, students who have a large vocabulary can convey their thoughts more freely and are not limited by ignorance of certain vocabulary.

\section{CONCLUSION}

Based on the calculations that have been done, it is proven that there is a significant correlation/effect of vocabulary mastery on students' speaking skills in English. This is evident from the results of hypothesis testing where the value of sig $=0.000$ and $\mathrm{t}_{\text {count }}=6.480$ while $\mathrm{t}_{\text {table }}=1.68$ so that the value of sig $<0.05$ and $t_{\text {count }}>t_{\text {table }}$ which means there is a significant effect.

\section{REFERENCES}

Alqahtani, M. (2015). The importance of vocabulary in language learning and how to be taught. International Journal of Teaching and Education, 3(3), 21-34.

August, D., Carlo, M., Dressler, C., \& Snow, C. (2005). The critical role of vocabulary development for English language learners. Learning Disabilities Research \& Practice, 20(1), 50-57.

Bahrani, T., \& Soltani, R. (2012). How to teach speaking skill. Journal of Education and Practice, 3(2), 25-29.

Bleed, P. (2008). Skill matters. Journal of Archaeological Method and Theory, 15(1), 154166.

Brown, H. D. (2000). Principles of language learning and teaching (Vol. 4). Longman New York.

Chatterjee, S., \& Hadi, A. S. (2015). Regression analysis by example. John Wiley \& Sons.

Gardner, R. C. (2001). Language learning motivation: The student, the teacher, and the researcher. Texas Papers in Foreign Language Education, 6(1), 1-18.

Gayratovna, R. H. (2021). ASSESSMENT FOR SPEAKING SKILL. ASSESSMENT, 7(4).

Givón, T. (2001). Syntax: an introduction (Vol. 1). John Benjamins Publishing.

Goh, C. C. M. (2016). Teaching speaking. In English Language Teaching Today (pp. 143159). Springer.

Gulati, C., \& Baber, P. (2020). Basics of statistics. In An SPSS Guide for Tourism, Hospitality and Events Researchers (pp. 106-123). Routledge.

Lussier, R. N., \& Achua, C. F. (2015). Leadership: Theory, application, \& skill development. Cengage learning.

Manurung, A. E. P. S., \& Manurung, S. (2020). SPEAKING SKILL Based On Video Dubbing Project: Based On Video Dubbing Project. Ayra Luna. 
Nygaard, L. C., \& Tzeng, C. Y. (2021). Perceptual integration of linguistic and nonlinguistic properties of speech. The Handbook of Speech Perception, 398-427.

Ott, R. L., \& Longnecker, M. T. (2015). An introduction to statistical methods and data analysis. Cengage Learning.

Read, J. (2007). Second language vocabulary assessment: Current practices and new directions. International Journal of English Studies, 7(2), 105-126.

Richards, J. C. (2008). Teaching listening and speaking. Cambridge university press Cambridge.

Robbins, S. P., \& Judge, T. (2012). Essentials of organizational behavior.

Schmitt, N., \& Schmitt, D. (2020). Vocabulary in language teaching. Cambridge university press.

Sugiyono. (2008). Metode Penelitian Kuatintatif, Kualitatif dan R\&D 2008. In Alfabeta.

Sugiyono. (2017). Statistika untuk Penelitian. Bandung: Penerbit Alfabeta. In Alfabeta.

Suryanto, B. T., \& Nikmatillah, U. (2020). The Effectiveness of CLT Method in Improving English Students Ability in KSK Institute of Fathimatuzzahro. IJOEEL: International Journal of English Education and Linguistics, 2(1), 1-8. 